\title{
PELATIHAN PEMBUATAN ARTIKEL ILMIAH \\ BAGI GURU GURU SMK SE-JAKARTA PUSAT
}

\author{
Supria Wiganda
}

Jurusan Teknik Mesin Fakultas Teknik Universitas Negeri Jakarta

\begin{abstract}
ABSTRAK
Kegiatan pelatihan Pembuatan Artikel Ilmiah ini bertujuan untuk; Melatih guruguru terampil dalam membuat Artikel Ilmiah dan karya tulis ilmiah, serta melatih guru dapat melaksanakan kegiatan penulisan sebagai upaya dalam rangka pengembangan profesinya.

Khlayak sasaran merupakan para guru-guru SMK baik negeri maupun swasta se jakarta Pusat. Pelatihan ini dilaksanakan dalam beberapa materi pertemuan yang ada kaitannya dengan pembuatan artikel Ilmiah yang dilaksanakan pada bulan September 2015 bertempat di SMK Negeri 39 Cempaka Putih Jakarta Pusat.

Pada Pertemuan tersebut diberikan secara umum tentang materi pembuatan Artikel ilmiah, teknik penulisan karya ilmiah serta teknik Presentasi, dan diakhiri dengan tugas pembuatan artikel ilmiah sesuai pedoman/panduan yang telah diberikan dalam pelatihan. Kegiatan ini dilaksanakan secara berkesinambungan dengan berbagai intitusi, yang antara lain unsur dinas pendidikan Kota Administratif Jakarta Pusat, pendidikan sekolah menengah kejuruan se wilayah jakarta pusat.

Evaluasi kegiatan dilakukan pada saat awal pelatihan, proses pelaksanaan pelatihan, dan diakhir kegiatan tes akhir, serta hasil pekerjaan dalam bentuk tugas membuat artikel ilmiah. Dari hasil selama pelatihan berlangsung memperlihatkan keantuiasan peserta sehingga berjalan secara hidup, dan dihasilkan produk artikel ilmiah dengan bervariasi judul, ini memperlihatkan keberhasilan pelatihan dengan baik.
\end{abstract}

Kata kunci : Pelatihan, Artikel ilmiah, dan Guru SMK

\section{PENDAHULUAN}


Pasca diberlakukannya PERMENPAN dan Reformasi Birokrasi no. 16 Tahun 2009 tentang Jabatan Fungsional Guru dan Angka Kreditnya, maka setiap guru yang ingin menaikan pangkatnya diberlakukan untuk membuat Pengembangan Keprofesian Berkelanjutan ( PKB) yang salah satunya membuat Penelitian Tindakan Kelas. Selain itu Pemerintah secara resmi telah mencanangkan bahwa profesi guru disejajarkan dengan profesi lainnya sebagai tenaga profesional. Pencanangan ini ditandai dengan undangundang Guru dan dosen yang dikeluarkan pada tahun 2005. Dengan ini diharapkan dapat meningkatkan mutu pendidikan, karena guru sebagai agen pembelajaran merupakan ujung tombak peningkatan proses pembelajaran di dalam kelas yang akan berujung pada peningkatan mutu pendidikan. Pengakuan kedudukan guru sebagai tenaga profesional dibuktikan dengan sebuah sertifikat profesi guru yang diperoleh melalui uji sertifikasi. Sertifikat pendidik diberikan kepada guru yang telah memenuhi persyaratan sebagai guru profesional.

Sertifikasi guru juga merupakan salah satu upaya pemerintah dalam meningkatkan kualitas guru sehingga pembelajaran di sekolah menjadi berkualitas. Peningkatan program lain yaitu; peningkatan kualifikasi akademik guru, peningkatan kompetensi guru, pembinaan karir guru, pemberian tunjangan guru, pemberian maslahat tambahan, penghargaan, dan perlindungan guru.

Selain hal-hal tersebut di atas secara garis besar juga terdapat beberapa kelompok kekurangan yang terjadi yang menyebabkan guru tidak lulus sertifikasi yang antara lain adalah pada kelompok penelitian dan karya ilmiah serta karya lainnya seperti buku ajar yang disusun sendiri oleh guru. Dalam pelaksanaan PKB hampir tidak pernah guru meneliti bidang pekerjaannya sendiri. Selain itu juga keaktifan dalam mengikuti PKB juga berbagai kegiatan penelitian atau karya ilmiah dan sejenisnya yang sangat kurang .
Berdasarkan pada kenyataan di atas dirasa perlu kiranya memberikan pelatihan pada guru dalam kaitannya dengan Pembuatan Artikel Ilmiah yang merupakan bagian dari pengem-bangan profesi guru.

Adapun rumusannya sebagai berikut:

a. Apakah dengan mengikuti pelatihan guru dapat membuat Artikel Ilmiah ?

b. Apakah dengan mengikuti pelatihan guru dapat membuat artikel ilmiah yang akan dipublikasikan dalam bentuk jurnal ?

Adapun Tujuan kegiatan ini : Melatih Guru membuat artikel ilmiah yang baik dan Melatih Guru untuk dapat menyusun, mempublikasikan dalam jurnal sebagai salah satu bahan untuk kenaikan pangkatnya.

\section{A. Hakekat Karya Tulis Ilmiah}

Karya tulis ilmiah adalah suatu karya tulis yang dibuat beracuan pada proses ilmiah. Suatu karya ilmiah (scientific paper) adalah laporan tertulis dan dipublikasi yang memaparkan hasil penelitian atau pengkajian yang telah dilakukan oleh seseorang atau sebuah tim dengan memenuhi kaidah dan etika keilmuan yang dikukuhkan dan ditaati oleh masyarakat keilmuan. Terdapat berbagai jenis karangan ilmiah, antara lain laporan penelitian, makalah seminar atau simposium, artikel jurnal, yang pada dasarnya kesemuanya itu merupakan produk dari kegiatan ilmuwan. Data, simpulan, dan informasi lain yang terkandung dalam karya ilmiah tersebut dijadikan acuan (referensi) bagi ilmuwan lain dalam melaksanakan penelitian atau pengkajian selanjutnya.

Sistematika suatu karya ilmiah sangat perlu disesuaikan dengan sistematika yang diminta oleh media publikasi (jurnal atau majalah ilmiah), sebab bila tidak sesuai akan 


\section{P-ISSN : 0216-7484 \\ DOI : doi.org/10.21009/sarwahita.121.06}

sulit untuk dimuat. Sedangkan suatu karya ilmiah tidak ada artinya sebelum dipublikasi. Walaupun ada keragaman permintaan penerbit tentang sistematika karya ilmiah yang akan dipublikasi, namun pada umumnya meminta penulis untuk menjawab empat pertanyaan berikut: (1) Apa yang menjadi masalah?; (2) Kerangka acuan teoretik apa yang dipakai untuk memecahkan masalah?; (3) Bagaimana cara yang telah dilakukan untuk memecahkan masalah itu?; (4) Apa yang ditemukan?; serta (5) Makna apa yang dapat diambil dari temuan itu?

Paparan tentang apa yang menjadi masalah dengan latar belakangnya biasanya dikemas dalam bagian Pendahuluan. Paparan tentang kerangka acuan teoretik yang digunakan dalam memecahkan masalah umumya dikemukakan dalan bagian dengan judul Kerangka Teoritis atau Teori atau Landasan Teori, atau Telaah Kepustakaan, atau label-label lain yang semacamnya. Paparan mengenai apa yang dilakukan dikemas dalam bagian yang seringkali diberi judul Metode atau Metodologi atau Prosedur atau Bahan dan Metode. Jawaban terhadap pertanyaan apa yang ditemukan umumnya dikemukakan dalam bagian Temuan atau Hasil Penelitian. Sementara itu paparan tentang makna dari temuan penelitian umumnya dikemukakan dalam bagian Diskusi atau Pembahasan. Tentu saja sistematika karya ilmiah ini tidak baku, atau harga mati. Sistematika karya ilmiah sangat bergantung pada tradisi masarakat keilmuan dalam bidang terkait, jenis karya ilmiah (makalah, laporan penelitian, skripsi). Dalam suatu karya ilmiah yang mempunyai tingkat keformalan yang tinggi, seperti misalnya skripsi, sistematika penulisan lebih baku, dan beberapa paparan lainnya sering diminta dari mahasiswa, seperti seperti Kesimpulan dan Rekomendasi (Saran-Saran) pada bagian akhir, atau Kata Pengantar pada bagian awal.
Banyak jurnal dan majalah meminta abstrak, yakni rangkuman informasi yang ada dalam dokumen laporan, makalah, atau skripsi, lengkapnya. Abstrak yang ditulis secara baik memungkinkan pembaca mengenali isi dokumen lengkap secara secara cepat dan akurat, untuk menentukan apakah isi dokumen sesuai dengan bidang minatnya, sehingga dokumen tersebut perlu dibaca lebih lanjut. Abstrak sebaiknya tidak lebih dari 250 kata (dalam satu atau dua paragraf), menyatakan secara singkat tujuan dan lingkup penelitian/pengkajian, metode yang digunakan, rangkuman hasil, serta kesimpulan yang ditarik.

\section{B. Hakikat Artikel Ilmiah}

Hakikat Karya Ilmiah Suatu Karya Ilmiah (scientific paper) adalah laporan tertulis dan dipublikasi yang memaparkan hasil penelitian atau pengkajian yang telah dilakukan oleh seseorang tau sebuah tim dengan memenuhi kaidah dan etika keilmuan yang dikukuhkan dan ditaati oleh masyarakat keilmuan.

Adapun tujuan dari penulisan karya ilmiah, antara lain untuk menyampaikan gagasan, memenuhi tugas dalam studi, untuk mendiskusikan gagasan dalam suatu pertemuan, mengikuti perlombaan, serta untuk menyebarluaskan ilmu pengetahuan / hasil penelitian. Karya ilmiah merupakan karya tulis yang menyajikan gagasan, deskripsi atau memecahan masalah secara sistematis, disajikan secara objektif dan jujur, dengan menggunakan bahasa baku, serta didukung oleh fakta, teori, dan atau bukti-bukti empirik.

Terdapat berbagai jenis karangan ilmiah, antara lain laporan penelitian, makalah seminar atau simposium, artikel jurnal, yang pada dasarnya kesemuanya itu merupakan produk dari kegiatan ilmuwan. Data, simpulan, dan informasi lain yang terkandung dalam karya ilmiah tersebut dijadikan acuan (referensi) bagi ilmuwan lain dalam melaksanakan penelitian atau pengkajian selanjutnya. Karya ilmiah dapat berfungsi 
sebagai rujukan, untuk meningkatkan wawasan, serta menyebarluaskan ilmu pengetahuan. Bagi penulis, menulis karya ilmiah bermanfaat untuk meningkatkan keterampilan membaca dan menulis, berlatih mengintegrasikan berbagai gagasan dan menyajikannya secara sistematis, memperluas wawasan, serta memberi kepuasan intelektual, di samping menyumbang terhadap perluasan cakrawala ilmu pengetahuan.

Dalam karya ilmiah ada 4 aspek yang menjadi karakteristik utamanya, yaitu :

1) Struktur sajian Struktur sajian karya ilmiah sangat ketat, biasanya terdiri dari bagian awal (pendahuluan), bagian inti (pokok pembahasan), dan bagian penutup. Bagian awal merupakan pengantar ke bagian inti, sedangkan inti merupakan sajian gagasan pokok yang ingin disampaikan yang dapat terdiri dari beberapa bab atau subtopik. Bagian penutup merupakan simpulan pokok pembahasan serta rekomendasi penulis tentang tindak lanjut gagasan tersebut.

2) Komponen dan substansi Komponen karya ilmiah bervariasi sesuai dengan jenisnya, namun semua karya ilmiah mengandung pendahuluan, bagian inti, penutup, dan daftar pustaka. Artikel ilmiah yang dimuat dalam jurnal mempersyaratkan adanya abstrak.

3) Sikap penulis dalam karya ilmiah adalah objektif, yang disampaikan dengan menggunakan gaya bahasa impersonal, dengan banyak menggunakan bentuk pasif, tanpa menggunakan kata ganti orang pertama atau kedua.

4) Penggunaan bahasa yang digunakan dalam karya ilmiah adalah bahasa baku yang tercermin dari pilihan kata/istilah, dan kalimat-kalimat yang efektif dengan struktur yang baku.

Adapun jenis - jenis karya ilmiah, yaitu :
1) Skripsi adalah karya tulis (ilmiah) mahasiswa untuk melengkapi syarat mendapatkan gelar sarjana (S1). Skripsi ditulis berdasarkan pendapat (teori) orang lain. Pendapat tersebut didukung data dan fakta empiris-objektif, baik berdasarkan penelitian langsung; observasi lapangan atau penelitian di laboratorium, atau studi kepustakaan. Skripsi menuntut kecer-matan metodologis hingga menggaransi ke arah sumbangan material berupa penemuan baru.

2) Tesis adalah jenis karya ilmiah yang bobot ilmiahnya lebih dalam dan tajam dibandingkan skripsi. Ditulis untuk menyelesaikan pendidikan pascasarjana. Dalam penulisannya dituntut kemampuan dalam menggunakan istilah tehnis; dari istilah sampai tabel, dari abstrak sampai bibliografi. Artinya, kemampuan mandiri sekalipun dipandu dosen pembimbing menjadi hal sangat mendasar. Sekalipun pada dasarnya sama dengan skripsi, tesis lebih dalam, tajam, dan dilakukan mandiri.

3) Disertasi ditulis berdasarkan penemuan (keilmuan) orisinil dimana penulis mengemukan dalil yang dibuktikan berdasarkan data dan fakta valid dengan analisis terinci. Disertasi memuat penemuan-penemuan baru, pandangan baru yang filosofis, tehnik atau metode baru tentang sesuatu sebagai cerminan pengembangan ilmu yang dikaji dalam taraf yang tinggi.

Dalam penulisan karya ilmiah ada 7 sikap ilmiah yang merupakan sikap yang harus ada. Sikap-sikap ilmiah yang dimaksud adalah sebagai berikut :

1) Sikap ingin tahu. Sikap ingin tahu ini terlihat pada kebiasaan bertanya tentang berbagai hal yang berkaitan dengan bidang kajiannya. 
2) Sikap kritis ini terlihat pada kebiasaan mencari informasi sebanyak mungkin berkaitan dengan bidang kajiannya untuk dibanding-banding kelebihan kekurangan-nya, kecocokan-tidaknya, kebenaran-tidaknya, dan sebagainya.

3) Sikap terbuka ini terlihat pada kebiasaan mau mendengarkan pendapat, argumentasi, kritik, dan keterangan orang lain, walaupun pada akhirnya pendapat, argumentasi, kritik, dan keterangan orang lain tersebut tidak diterima karena tidak sepaham atau tidak sesuai.

4) Sikap objektif. Sikap objektif ini terlihat pada kebiasaan menyatakan apa adanya, tanpa diikuti perasaan pribadi.

5) Sikap rela menghargai karya orang lain. Sikap menghargai karya orang lain ini terlihat pada kebiasaan menyebutkan sumber secara jelas sekiranya pernyataan atau pendapat yang disampaikan memang berasal dari pernyataan atau pendapat orang lain.

6) Sikap berani mempertahankan kebenaran. Sikap ini menampak pada ketegaran membela fakta dan hasil temuan lapangan atau pengembangan walapun bertentangan atau tidak sesuai dengan teori atau dalil yang ada.

7) Sikap menjangkau ke depan. Sikap ini dibuktikan dengan selalu ingin membuktikan hipotesis yang disusunnya demi pengembangan bidang ilmunya.

Kesalahan dalam penulisan Karya Ilmiah Rata-rata kesalahan penulisan karya ilmiah yang menghambat penyelesaiannya adakan dikarenakan 'tidak konsisten' dalam penulisan. Bentuk ketidak konsisten itu menyangkut banyak hal, dapat berupa diksi, teknik mengutip, atau bahkan alur berpikir sendiri. Berbagai kendala yang jumpai dalam proses penulisan penelitian ilmiah adalah sebagai berikut :
- salah mengerti audience atau pembaca tulisannya,

- salah dalam menyusun struktur pelaporan,

- salah dalam cara mengutip pendapat orang lain sehingga berkesan menjiplak (plagiat),

- salah dalam menuliskan bagian Kesimpulan,

- penggunaan Bahasa Indonesia yang belum baik dan benar,

- tata cara penulisan "Daftar Pustaka" yang kurang tepat (tidak standar dan berkesan seenaknya sendiri),

- tidak konsisten dalam format tampilan (font yang berubah-ubah, margin yang berubah-ubah).

\section{Hakekat Pengembangan Profesi}

Pekerjaan profeisonal dapat dikelompokkan ke dalam dua katagori: yaitu Hard Profession dan Soft Profession. Suatu pekerjaan dapat dapat dikatagorikan sebagai Hard Profession apabila pekerjaan tersebut dapat didetailkan dalam perilaku dan langkahlangkah yang jelas dan yang relatif pasti. Pendidikan yang diperlukan bagi profesi ini adalah menghasilkan keluaran pendidikan yang dapat distandarisasikan. Artinya, kualifikasi lulusan jelas dan seragam di manapun pendidikan itu berlangsung. Dengan kulifikasi ini seseorang sudah mampu dan akan terus mampu melaksanakan tugas profesinya secara mandiri tanpa pendidikan lagi. Pekerjaan dokter dan pilot sebagai contohnya. Sebaliknya katagori Soft Profession adalah diperlukannya kadar seni dalam melasanakaan pekerjaan tersebut. Ciri pekerjaan tersebut tidak dapat dijabarkan secara detail dan pasti. Sebab, langkah-langkah dan tindakan yang harus diambil, sangat ditentukan oleh kondisi dan stuasi tertentu. Implikasi katagori Soft Profession tidak menuntut pendidikan yang dapat menghasilkan lulusan dengan standar tertentu melainkan menuntut lulusan dibekali dengan kemampuan minimal. Kemampuan ini 
dari waktu ke waktu harus ditingkatkan agar dapat melaksanakan tugas pekerjaannya sesuai dengan perkembangan masyarakat. Oleh karena itu, lembaga in - service training bagi Soft Profession amat penting. Profesi Guru termasuk dalam katagori Soft Profession. Sehingga dirasakan perlu atau secara rasonal dapat kiranya program sertifikasi guru ini dibenarkan. Karena dengan program sertifikasi ini akan membawa kepada mutu pendidikan yang lebih baik.

Sertifikasi guru merupakan salah satu upaya pemerintah dalam meningkatkan kualitas guru sehingga pembelajaran di sekolah menjadi berkualitas. Peningkatan program lain yaitu; peningkatan kualifikasi akademik guru menjadi S1/D4, peningkatan kompetensi guru, pembinaan karir guru, pemberian tunjangan guru, pemberian maslahat tambahan, penghargaan, dan perlindungan guru. Tugas seorang guru dilihat dari profesi adalah :

1. Mendidik : Meneruskan dan mengembangkan nilai-nilai hidup.

2. Mengajar : Meneruskan dan mengembangkan iptek.

3. Melatih : Mengembangkan keterampilan dan penerapannya.

Sementara tugas seorang guru sebagai tugas kemanusiaan adalah :

1) Menjadi orang tua kedua,

2) Transformasi diri, dan

3) Autoidentifikasi. Guru juga mengemban tugas kemasyarakatan yang antara lain: Mendidik dan mengajar masyarakat untuk menjadi WNI yang bermoral Pancasila, dan Mencerdaskan bangsa Indonesia

Guru profesional dan bermartabat menjadi impian kita semua karena akan melahirkan anak bangsa yang cerdas, kritis, inovatif, demokratis, dan berakhlak. Guru profesional dan bermartabat memberikan teladan bagi terbentuknya kualitas sumber daya manusia yang kuat. Sertifikasi guru mendulang harapan agar terwujudnya impian tersebut. Perwujudan impian ini tidak seperti membalik talapak tangan. Karena itu, perlu kerja keras dan sinergi dari semua pihak yakni, pemerintah pusat, pemerintah daerah, masyarakat, dan guru.

Didalam undang-undang guru dan dosen dinyatakan ada empat kompetensi profesi guru yaitu :

1) Kompetensi Pedagogik, Kemampuan mengelola pembelajaran peserta didik.

2) Kompetensi Kepribadian, Kemampuan kepribadian yang mantap, berakhlak mulia, arif dan berwibawa serta menjadi teladan peserta didik.

3) Kompetensi Profesional, kemampuan penguasaan materi pelajaran secara luas dan mendalam. Dan

4) Kompetensi Sosial, Kemampuan untuk berkomunikasi dan berinteraksi secara efektif dan efisien dengan peserta didik, sesama guru, orangtua/wali dan masyarakat sekitar. Keempat komponen kompetensi guru ini dijabarkan ke dalam 10 kompetensi.

Selain hal tersebut di atas kita juga mengenal 10 kompetensi guru yaitu :

1) Menguasai bahan pelajaran,

2) Mengelola PBM,

3) Mengelola Kelas,

4) Menggunakan media/sumber belajar,

5) Mengguasai landasan pendidikan,

6) Mengelola interaksi belajar mengajar,

7) Menilai prestasi siswa,

8) Mengenal layanan BK,

9) Mengenal Penyelenggaraan. Administrasi Sekolah, dan

10) Memahami prinsip-prinsip Penelitian Pendidkan.

Sertifikasi guru melalui uji kompetensi memperhitungkan pengalaman profesionalitas guru, melalui penilaian portofolio guru. Sepuluh komponen portofolio guru akan dinilai oleh perguruan tinggi penyelenggara sertifikasi guru. 


\section{METODE}

Pemecahan masalah tentang Peningkatan Layanan Pendidikan Dalam Proses Pembelajaran di Sekolah dengan mengadakan pelaksanakan pelatihan Penulisan artikel ilmiah bagi guru- guru SMK dalam dua tahap, yaitu tahap pertama tentang pemberian materi teori secara keseluruhan dan tahapan berikutnya adalah latihan membuat artikel ilmiah sampai berhasil menjadi produk.

\section{A. Realita Pemecahan Masalah}

Sebagai realita pemecahan masalah seluruh para peserta pelatihan dapat menghasilkan karya dalam bentuk artikel ilmiah yang didasarkan dari Penelitian Tindakan Kelas dengan mengaplikasikan model/metode pembelajaran yang didapat pada pelatihan sehingga muncul hasil,berbagai variasi judul, yang dapat dilaksanakan di sekolah masing-masing.

\section{B. Khalayak Sasaran}

Guru-guru yang akan mengusulkan naik pangkat atau sedang menyelesaikan program pendidikan di pendidikan tinggi sebagai contoh mahasiswa yang dalam hal ini adalah guru yang sedang membuat skripsi, Tesis maupun Disertasinya.

\section{Metode Penerapan Ipteks}

Pada pelatihan ini dilaksanakan sebanyak 6 pertemuan yang masing-masing selama 1,5 jam. Pada pertemuan pertama diberikan secara umum tentang penulisan Artikel Ilmiah. Pada pertemuan 2 sampai ke 5 latihan penerapan pembuatan Artikel ilmiah dan pertemuan ke 6 evaluasi.

\section{Keterkaitan}

Kegiatan yang dilaksanakan ini mempunyai keterkaitan dengan berbagai institusi, yang antara lain adalah institusi/dinas pendidikan pada umumnya dan pendidikan menengah, baik bidang sekolah menengah kejuruan maupun umum di wilayah Jakarta Pusat.

Evaluasi kegiatan dilakukan tidak saja di akhir dari program pelatihan juga selama proses dilakukan juga evaluasi pada peserta pelatihan. Jadi di awal program diberikan tes awal, di sepanjang pelatihan ada kuis tiap bahasan, dan diakhir program juga ada tes akhir. Serta juga hasil pekerjaan selama proses pelatihan juga dihimpun.

\section{HASIL DAN PEMBAHASAN}

\section{A. Hasil Kegiatan}

Evaluasi kegiatan dilakukan tidak saja di akhir dari program pelatihan juga selama proses dilakukan juga evaluasi pada peserta pelatihan. Jadi di awal program diberikan tes awal, di sepanjang pelatihan ada kuis tiap bahasan, dan diakhir program juga ada tes akhir. Serta juga hasil pekerjaan selama proses pelatihan dalam bentuk proposal penelitian.

Dari hasil observasi selanma pelatihan berlangsung memperlihatkan keseriusan dan keantusiasan peserta sehingga interaktif berjalan secara hidup dan produk Artikel yang dihasilkanpun sangat baik dan bervariatif.

\section{B. Pembahasan}

Berikut ini dipaparkan hasil kegiatan program pengabdian masyarakat untuk guruguru SMK se Jakarta Pusat:

Pada kegiatan ini diadakan evaluasi terhadap peserta dan evaluasi terhadap program kegiatan. Evaluasi terhadap peserta dilakukan oleh anggota tim terhadap proses dan hasil yang dicapai secara obyektif. Sedangkan Evaluasi terhadap program kegiatan dilakukan oleh pelaksana untuk mengetahui tingkat ketercapaian tujuan kegiatan yang dilaksanakan. Kegiatan evaluasi dilaksanakan sebelum, selama dan sesudah kegiatan pelatihan ini berlangsung. Evaluasi sebelum kegiatan dilaksanakan dengan cara diskusi dengan para anggota sebelum pelaksanakaan pemaparan materi; sedangkan evaluasi selama 
kegiatan berlangsung dilakaukan dengan mengamati peserta peltihan. Dan setelah itu dilakukan evaluasi dengan cara membuat masing-masing artikel ilmiah yang akan diajukan oleh masing-masing guru.

Atas dasar pengamatan selama pelaksanaan pelatihan berlangsung seluruh peserta sangat perhatian dan serius dalam membuat tugasnya serta adanya perubahan perilaku dalam berdiskusi yang cukup baik. Yang saat awal pertemuan belum terbuka wawasannya tentang pengetahuan karya tulis ilmiah, sekarang cukup memiliki kemampuan untuk menulis sebuah artikel ilmiah, hal ini mengindikasikan bahwa pelatihan yang diadakan sudah cukup berhasil.

Selain itu dapat terlihat dengan berbagai variasi judul artikel yang dihasilkan oleh para peserta, juga memperlihatkan bahwa kemampuan para peserta dalam memecahkan berbagai masalah di kelas melalui sebuah penelitiannya, sehingga memperlihatkan kemampuan atau keberhasilan yang sangat baik bagi peserta.

\section{Faktor Pendorong Dan Penghambat}

Adapun faktor pendorong dalam kegiatan ini adalah adanya kesungguhan dari seluruh peserta guru-guru SMK serta para Kepala Sekolah SMK masing yang telah memberikan izin dan tugas kepada gurugurunya. Juga Kepala Sekolah SMKN 39 Jakarta yang telah memberikan kesempatan untuk menjadi tuan rumah dalam pelaksanaan pelatihan serta membantu berbagai sarana prasarana dan akomodasi demi kelancaran pelaksanaan pelatihan penulisan artikel ilmiah di wilayah Jakarta pusat yang telah diberikan kepada pelaksana Pengabdian Masyarakat LPM Universitas Negeri Jakarta, sehingga berjalan sesuai dengan jadwal yang telah ditentukan sebelumnya.

Adapun faktor penghambat dalam pelatihan ini dapat dikatakan tidak ada, kecuali faktor dana yang terbatas, sehingga jumlah peserta dibatasi, sarana prasara yang diberikan kepada para peserta pelatihan juga kepada para pelatihan sangat terbatas pula.

\section{KESIMPULAN}

Sebagai kesimpulan dari hasil kegiatan pelatihan Penulisan Artikel Ilmiah adalah sebagai berikut:

1. Para peserta mengetahui konsep dasar karya tulis ilmiah secara mendalam, sehingga memiliki kemampuan untuk membuat suatu karya tulis ilmiah dalam bentuk artikel jurnal.

2. Para peserta mendapat kemampuan dan wawasan karya tulis ilmiah secara prosedural.

3. Dengan adanya berbagai variasi judul dalam artikel ilmiah yang telah dibuat para peserta, mengindikasikan bahwa wawasan serta kemampuan mengenai karya tulis ilmiah dalam hal ini artikel ilmiah bagi peserta ternyata meningkat.

4. Hasil pelatihan dapat diaplikasikan secara jelas, dan juga dapat membantu/ mempercepat dalam penulisan karya ilmiah lain bagi guru-guru yang sedang membuat tesis maupun disertasinya.

\section{DAFTAR PUSTAKA}

APA, 1983. Publication Manual of the American Psychological Association Third Edition. Washington DC: American Psychological Association.

Barlow, Daniel Lenox. 1985. Educational Psychology: The Teaching LearningProcees. Chiocago: The Moody Bible Institute.

Bloom, Benyamin S. 1976. Human Characteristic and School Learning. New York: Mc Graw-Hill Book Company. 
Depdikbud, Ditjen Pendidikan Dasar dan menengah. 1999. Penelitian Tindakan. Jakarta: Dikmenum.

Hopkins, D. 1985. A Teacher"s. Guide to Classroom Research. Philadelphia: Open University Press.

Santoso, Singgih. 2000. Buku Latihan SPSS Statistik Parametrik. Jakarta: Elex Media Komputindo.

Santoso, Singgih. 2007. Soal Jawab Statistik dengan SPSS dan Exel. Jakarta: Elex Media Komputindo.

Sarwono, Jonathan. 2007. Analisis jalur Untyuk Riset bisnis Dengan SPSS. Yogyakarta: Penerbit Andi.
Suwarsih Madya. 2006. Teori dan Praktik Penelitian Tindakan. Bandung: Alfabeta.

Thorndike R.L \& E.P. Hagen, 1977. Measurement and Evaluation in Psychology and Education. New York: John Wiley \& Sons.

Wilkinson, David, 2000. The Researcher's Toolkit The Complete Guide to Practioner Research. London: Routledge Falmer 